\title{
地域で暮らす統合失調症患者に対する精神科訪問看護の役割 一精神科訪問看護利用者の特性と再入院との関連要因一
}

\author{
定村 美紀子 奥野 純子 山川 百合子 柳 久子
}

\begin{abstract}
要約
【目的】精神科訪問看護利用者の特性と訪問看護利用者の調査後の入院の有無に関連する要因を明 らかにする。

【方法】精神科外来に通院する統合失調症患者で訪問看護利用者 (55 名) 非利用者 (31 名) を対象に, 質問紙による面接調査を実施し両群間で特性を比較した。 また, 平均 9 力月間の入院の有無と関連 する要因を検討した，調査項目は，年齢，性別，家族状況，精神症状，服薬態度，自己効力感など であった.

【結果】全対象者の $86 \%$ は家族と同居していたが, 訪問看護利用者は非利用者と比較して独居の割 合が高く, 年齢も高く, 調査直近の入院期間が長く退院後の期間が短いなど継続した支援を必要と している者が多かった．また，訪問看護利用者で入院した者は自己効力感が高かった.

【結論】家族の支援が困難で, 症状が重度な統合失調症患者でも訪問看護を利用することで在宅生 活が可能となることが示唆された. また, 患者が自己の能力を適切に判断し, 疾病管理ができるよ うな働きかけが訪問看護に求められている.
\end{abstract}

Key Words:

統合失調症, 精神科訪問看護, 地域医療福祉, 自己効力感

$$
\text { 〔日本プライマリ・ケア連合学会誌２011, vol.34,no.1,p. } 6 \text { - 13 }
$$

\section{I . はじめに}

諸外国では 1970 年代以降, 入院医療から地域生活 支援へと精神科医療政策の転換が図られ，地域支援体 制が確立されてきた ${ }^{1)}$.しかし，わが国は 1950 年の 精神衛生法の制定以降, 精神病床が急速に增加し長期 入院患者の社会復帰が進まない現状がある ${ }^{2)}$.

精神科に入院している患者の 7 万人弱が退院の見込 みがある者と言われ，2004 年に厚生労働省は，地域 生活支援体制の強化を目指寸「精神保健医療福祉の改
革ビジョン」を策定した ${ }^{2)}$. 認知症に次いで入院が長 期化しやすい統合失調症の入院を短縮することが, 改 革ビジョンの目標を達成する鍵となる ${ }^{3)}$.

統合失調症患者の罹病危険率は, $0.7 \sim 0.8 \%{ }^{4)}$ で精 神科の入院患者の約 $60 \%$ を占める疾患である ${ }^{5}$. 2002 年に「精神分裂病」から「統合失調症」に改 められたが積極的に病名を告知しないことや，病識の 欠如, 生活リズムの乱れ, 服薬の中断等によって再発

定村 美紀子 奥野 純子 柳 久子 筑波大学大学院 人間総合科学研究科 ヒューマン・ケア科学専攻 福祉医療学

山川 百合子 茨城県立医療大学医科学センター

著者連絡先：奥野純子

筑波大学大学院 人間総合科学研究科 ヒューマン・ケア科学専攻 福祉医療学

( † 305-8577 茨城県つくば市天王台 1 - 1 - 1 総合研究棟 D, E-mail: okunoj@md.tsukuba.ac.jp) 
するケースも少なくない6)

長期入院患者の社会復帰が進まない理由として,「退 院後の生活不安」,「家族の高齢化」,「社会的偏見」,「住 居の確保が困難」等があげられ ${ }^{78)}$ ，精神障害者が安 心して生活できる環境を整えることは，地域精神保健 医療福祉の重要な課題である.

精神疾患をもつ患者の自宅を訪問し援助を行う制度 に「精神科訪問看護」がある。1986 年より，患者の 居宅において看護師や精神保健福祉士などが，患者又 は家族等に看護, 療養指導及び社会復帰指導等を行っ た場合に「精神科訪問看護・指導料」として診療報酬 を算定できるようになった ${ }^{4)}$. 患者の再発の兆候を早 期に発見することや，家族に対し疾患の理解や社会資 源の活用に関する助言を行う等精神障害者の地域生活 を支援する事業として期待されている。

地域で生活する精神障害者に対する海外の研究で は，退院後，看護師等が在宅ケアを提供することによ り, 服薬の継続, QOL の向上, 再入院の抑制に有効で, 医療費の削減に効果があると報告されている ${ }^{9100}$ 。わ が国においても，訪問看護利用者の入院日数が減少し たという報告がある ${ }^{111}$.

しかし，精神科訪問看護利用者の特性や精神科訪問 看護の利用と再入院, 精神症状, 服薬態度, 自己効力 感等との関連についての研究はみあたらない,そこで, 本研究は, 訪問看護利用者 (以下, 訪問群) とその他 の者 (以下, 非訪問群) の比較を行い，1) 精神科訪問 看護の利用者の特性の明確化，2) 訪問看護利用者の再 入院の有無と関連のある要因を明らかにすることを目 的とした.

\section{II. 研究方法}

\section{1.「精神科訪問看護」について}

本研究の「訪問看護」とは，精神科を標榜している 保険医療機関において医師の指示を受けた保健師，看 護師，作業療法士又は精神保健福祉士が二人一組にな $\eta$, 外来患者又はその家族等の了解を得て週に $1 \sim 2$ 回 (30 分程度) 患者の自宅を訪問し, 個別に患者又は 家族等に対して生活りズムや服薬の確認，社会復帰支 援などを行うものである.

\section{2. 対象}

茨城県南部にある $\mathrm{A}$ 病院 (精神科)の外来患者で統 合失調症と診断された者を対象とした。除外基準は， 20 歳未満, 症状が不安定な者, 主治医または担当看 護師がコミュニケーションに問題があると判断した者 とした。A 病院の訪問看護登録者 (120 名) から 2008
年 10 月〜 2009 年 11 月の訪問看護利用者で条件を満 たした 58 名に研究の説明を行い調査の同意が得られ た 55 名を訪問群とした。訪問看護を利用していない 者については，A病院のデイケア参加者で上記の条 件を満たす者の中から調査を拒否する者を除いた 18 名及び $\mathrm{A}$ 病院の 2008 年 11 月と 2009 年 9 月の外来患 者 (概数約 40 名/日)にB医師の協力を得て実施した。

B 医師の外来は, 週 2 回であり, (概数 320 名 /月), 1 回 10 名 $(25 \%)$ に声をかけて最終的に同意を得た患 者が 13 名で, 計 31 名が非訪問群である.

\section{3. 調查方法}

本研究の調查期間は，2008 年 10 月～2009 年 11 月 である。調査方法は，質問紙による面接聞き取り調査 である１）訪問群の場合，対象者の自宅で訪問看護終 了後, 研究の趣旨を説明し面接による調查を実施した。 2) 非訪問群の場合, 外来診療の待ち時間やデイケアの 自由時間を利用し，面接による調查を実施した。罹病 期間, 入院期間や回数など, 記憶が不明確な情報につ いては，本人の了解を得て外来診療録を参照した，面 接は,他の患者などに内容が聞こえないように配虑し， 離れた場所で実施した。

なお, 訪問群の初回調查後の入院の有無は, 初回調 査から 2009 年 11 月 30 日までの入院の有無, 入院回数, 入院月日, 総入院日数および入院形態 $($ 任意・医療保 護入院) を外来診療録から調査した。

\section{4. 調查内容}

1) 調査項目: 年齢, 性別, 婚姻·同居の有無, 教育歴, 経济状況 ( (1)就労の有無, (2)障害年金, (3)生活保護, (4) 家族の支援), 日中の活動, 過去の服薬問題 (多量 服薬等), 服薬中断の有無, 服薬管理方法, 受診困難· 薬剤師に相談の有無, 精神症状, 病識を調査した。

(1) 精神症状

簡易精神症状評価尺度 ${ }^{22)}$ : Brief Psychiatric Rating Scale(BPRS : 以下 BPRS) と機能の全体的評定尺度 ${ }^{4)}$ : The Global Assessment of Functioning(GAF ; 以下 GAF) を使用した. BPRS は, 精神症状を 1 (症状なし) から 7 (最重度) で評価し, 症状が重度であると得点が 高い. GAF は，心理・社会・職業的機能を $0 \sim 100$ で評価する，得点が高いほど社会生活機能が高いこと を意味する。

(2) 病識

日本語版病識評価尺度: The Schedule for Assessment of Insight(SAI-J ; 以下 SAI-J) ${ }^{13)}$ を使用し た. SAI-Jは, 治療と服薬の必要性, 疾病についての 意識を評価する。点数が高いほど病識が高い。 


\section{表 1 訪問群と非訪問群の特性の比較}

\begin{tabular}{|c|c|c|c|}
\hline & 訪閭群（n=55） & 非訪問群 $(n=31)$ & $\mathrm{p}$ 值 \\
\hline 年糕 (歳) & $44.7 \pm 11.6$ & $35.9 \pm 9.2$ & $* *$ \\
\hline 男性 & $31(56.4 \%)$ & $15\left(48.4_{\%}^{\%}\right)$ & ns \\
\hline 婚姻 & $11(20.0 \%)$ & $4(12.9 \%)$ & ns \\
\hline 家族と同居している & $44(80.0 \%)$ & $30(96.8 \%)$ & $*$ \\
\hline 教育歷 & & & ns \\
\hline · 中学校 & $15(27.3 \%)$ & $7(22.6 \%)$ & \\
\hline ·高等学校 & $32(58.2 \%)$ & $17(54.8 \%)$ & \\
\hline ·専門学校·短大·大学 & $8(14.5 \%)$ & $7\left(22.6_{\%}^{o}\right)$ & \\
\hline \multicolumn{4}{|l|}{ 経済状況 } \\
\hline (1)現在仕事がある & $1(1.8 \%)$ & $6(19.4 \%)$ & $* *$ \\
\hline (2)障害年金老受給 & $28(50.9 \%)$ & $14\left(45.2_{\%}^{o}\right)$ & $\mathrm{ns}$ \\
\hline (3)生活保護を受給 & $8(14.5 \%)$ & $2(6.5 \%)$ & ns \\
\hline (4)家族の収入で生活 & $32(58.2 \%)$ & $25(80.6 \%)$ & $*$ \\
\hline \multicolumn{4}{|l|}{ 日中の活動 } \\
\hline ・ディケアに通っている & $23(41.8 \%)$ & $15(48.4 \%)$ & ns \\
\hline ·作業所等に通っている & $7(12.7 \%)$ & $10(32.3 \%)$ & * \\
\hline 罹病期間 (年) a) & $15.1 \pm 9.8$ & $10.0 \pm 6.1$ & $*$ \\
\hline 直近の人院日数 ${ }^{b)}$ & $454.6 \pm 848.1$ & $110.5 \pm 133.6$ & * \\
\hline 退院から調査日本での日数 & $464.8 \pm 621.1$ & $1193.3 \pm 1204.3$ & $* *$ \\
\hline
\end{tabular}

2) 質問項目 : 服薬態度，地域生活に対する自己効力感

(1) 服薬態度

Drug Attitude Inventory(DAI-10 ; 以下 DAI-10) 老 使用した。 DAI-10は，服薬に関する 10 項目の質問で 構成された自記式評価尺度 ${ }^{14)}$ で，日本語版において も内的整合性と信頼性が確認されている ${ }^{15)}$. 肯定的回 答 (+1 点), 否定的回答 (-1 点) t合計し, 得点が高い ほど薬物療法における主観的 QOL が高いことを示す。

(2) 地域生活に対する自己効力感

Self-Efficacy for Community Living(SECL ; 以下 SECL) $)^{16)}$ を用いた. SECL は, 統合失調症患者の地域 生活に対する自己効力感をみる尺度で, (1)日常生活 5 項目, (2)治療行動 4 項目, (3)症状対処行動 4 項目, (4) 社会生活 3 項目, (5)対人関係 2 項目の 5 領域 18 項目 の質問に対する主観的自信を 0 〜 10 の 11 段階で評価 する，得点が高いほど自己効力感が高いことを示す 17).

\section{3) 外来診療録からの情報}

罹病期間, 入院回数，直近の入院期間，直近の退院か ら調査日までの日数。罹病期間は, 精神症状が出現し 最初に精神科を受診した年から調査日までの年数とし た。

\section{5. 統計学的解析方法}

数值は, 平均 $\pm \mathrm{SD}$ であらわした. 2 群間の比較には, 順序尺度の場合は Mann-Whitney のU 検定を用いて
中央値を比較し，カテゴリ変数の比較には $\chi^{2}$ 検定を 用い, $\mathrm{n}$ が少ない場合は, Fisher の直接確率計算法を 用いた。相関係数は, Spearman 順位相関係数を用い て 1) 訪問群と非訪問群の初回調查時の特性の比較, 2) 訪問群を対象とし, 初回調査後平均 9 力月間に入院し た者 (以下, 入院群) としなかった者 (以下, 非入院群) の特性を比較した。解析には統計ソフトSPSS14.0 J for Windows を用い有意水準は $5 \%$ 未満とした。

\section{6. 倫理的配慮}

研究の実施について，筑波大学医の倫理審査委員会 の承認を得た。また, $\mathrm{A}$ 病院の倫理審査会に研究計 画書を提出し, 主治医の承諾及び外来診療録の閲覧に ついて承認を得た。対象者に対する倫理的手続きとし ては, 外来診療録の閲覧の許可, 調査結果は厳重に保 管し本研究以外に使用しないこと, 調査への参加は自 由で参加しなくても不利益を受けることがないこと， 同意後いつでも参加を取り消すことができることを口 頭及び書面で説明し同意を得た。

\section{III. 研究結果 \\ 1. 対象者の特性}

表 1 に対象者の基本属性を示す。対象者は，訪問 群 55 名，非訪問群 31 名であった。全対象者の 53.5\% が男性で平均年齢 $( \pm \mathrm{SD}) 41.5( \pm 11.5)$ 歳であった。 性差に両群間で差はなかったが, 平均年齢 $( \pm \mathrm{SD})$ は, 訪問群 44.7 \pm 11.6) 歳は非訪問群 35.9( \pm 9.2) 歳に比 


\section{表 2. 訪問群と非訪問群の精神症状、地域生活における自己効力感、服薬状況の比較}

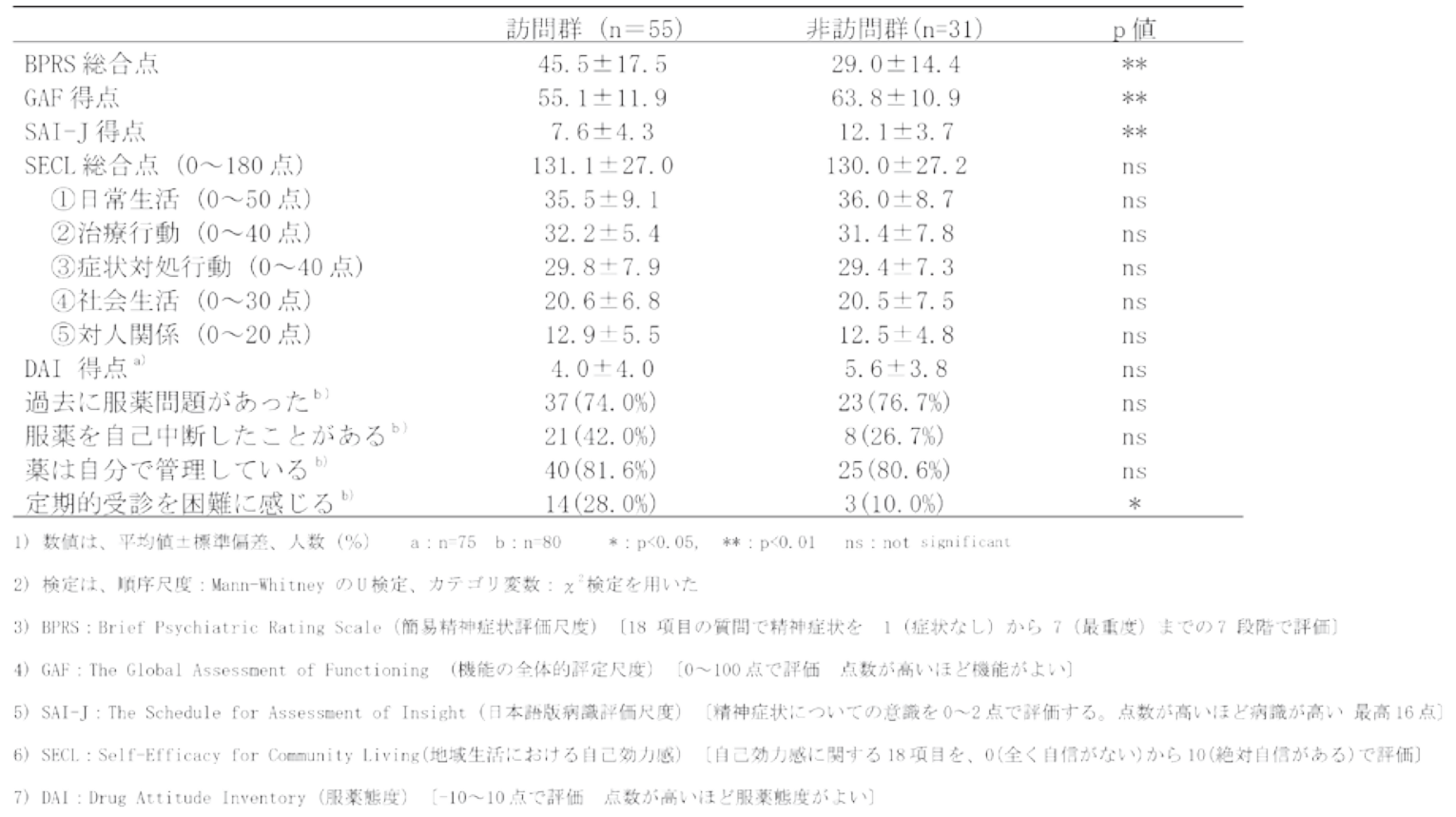

し有意に高く $(\mathrm{p}<0.01)$, 家族との同居割合 $(80.0 \% \mathrm{vs}$ $96.8 \%)$ ，家族の収入で生活の割合 $(58.2 \%$ vs $80.6 \%)$ は 訪問群が有意に低かった $(\mathrm{p}<0.05)$. 訪問群と非訪問群 の罹病期間は, 〔15.1( \pm 9.8$)$ 年 vs $10.0( \pm 6.1)$ 年 , 直 近の入院日数は，〔454.6( \pm 848.1) 日 vs $110.5( \pm 133.6)$ 日」で訪問群が有意に長かった $(\mathrm{p}<0.05)$. 退院から調 査日までの日数 (平均 $\pm \mathrm{SD})$ は, 訪問群〔464.8( \pm 621.1) 日〕は，非訪問群〔1193.3( \pm 1204.3$)$ 日〕に比 し有意に短かった $(\mathrm{p}<0.01)$.

\section{2. 精神症状, 自己効力感, 服薬状況の比較 (表 2)}

BPRS 合計平均点 ( \pm SD) は, 訪問群 45.5( \pm 17.5) 点は, 非訪問群 29.0( \pm 14.4) 点に比し有意に高く精神 症状が重度であった $(\mathrm{p}<0.01)$. また, GAF 平均点 $( \pm$ SD) は, 〔55.1( \pm 11.9$)$ 点 vs $63.8( \pm 10.9)$ 点 〕, SAI-J 平均点 $( \pm \mathrm{SD})$ は, $〔 7.6( \pm 4.3)$ 点 vs $12.1( \pm 3.7)$ 点 $]$ でいずれも訪問群が有意に低かった $(\mathrm{p}<0.01)$. 定期的 受診を困難に感じる者の割合は，〔28.0\% vs 10.0\%〕 で訪問群が有意に高かった $(\mathrm{p}<0.05)$.

\section{3. 訪問群における再入院とその関連要因 (表 3)(表 4)} 訪問群 55 名の初回調査後の入院の有無を調査した. 初回調査後平均 9 力月間に入院した者 (入院群) は, 19 名おり全体の $34.5 \%$ を占めていた。 入院形態は, 任意 12 名 $(63.2 \%)$, 医療保護 7 名 (36.8\%) であった。 初回調査日から入院までの平均日数は, $117.3 \pm$ 70.4 日 (8 日-224日)であった。 入院群の男性は $57.9 \%$, 平均年齢 $( \pm \mathrm{SD}) 42.6( \pm 12.0)$ 歳であり,
BPRS，GAF，SAI-J，DAIの得点に非入院群と差は なかった。しかし, BPRSの下位項目の「誇大性」は, 入院群 $3.2( \pm 1.8)$ 点は非入院群 $1.9( \pm 1.4)$ 点に比し有 意に高かった $(\mathrm{p}<0.01)$. 地域生活に対する自己効力感 を示す SECL の総得点の平均点 $( \pm \mathrm{SD})$ は, 入院群 $146.5( \pm 19.2)$ 点で非入院群 $122.9( \pm 27.1)$ 点と比較し て有意に高かった $(\mathrm{p}<0.01)$ 。さらに，非入院群では BPRS と SECL に負の相関が認められ, 精神症状と自 己効力感に関連がみられたが $(r=-0.27, \mathrm{p}<0.05)$, 入院 群では認められなかった (データの表示なし).

\section{IV. 考察}

\section{1. 精神科訪問看護の利用者の特性}

統合失調症の外来患者で訪問看護利用者の特性を明 らかにすることを目的に，訪問看護利用者 (訪問群) とその他の者 (非訪問群) を比較した。日本精神科病 院協会の調査 ${ }^{18)}$ による , 精神科外来患者の平均年 齢は 46.6( \pm 15.3) 歳, 男性 51.6\%，家族と同居の割合 $76.8 \%$ ，就労していない割合 $77.3 \%$, GAF の平均得点 59.1( \pm 15.0$)$ 点であり，本研究の対象者は一般的な精 神科外来患者と大きな違いはなかった。

本研究の訪問群は, 非訪問群と比較し, 調査直近の 入院日数が長く $(\mathrm{p}<0.05)$, 退院から調査日までの日数 が短く $(\mathrm{p}<0.01)$ 退院後間もない患者であり, BPRS が 有意に高く $(\mathrm{p}<0.01), \mathrm{GAF}$ と SAI-J(病識) が有意に 低いこと $(\mathrm{p}<0.01)$ から, 訪問看護利用者は, 症状が不 
表 3. 初回調査後の入院群と非入院群の特性の比較一訪問群を対象として一

\begin{tabular}{|c|c|c|c|}
\hline & 入院群 $(n=19)$ & 非入院群 $(\mathrm{n}=36)$ & $\mathrm{p}$ 值 \\
\hline 年踇 (藏) & $42.6 \pm 12.0$ & $45.8 \pm 11.3$ & ns \\
\hline 男性 & $11(57.9 \%)$ & $20(55.6 \%)$ & ns \\
\hline 婚㚵 & $1(5.3 \%)$ & $10(27.8 \%)$ & * \\
\hline 家族と同居している & $17(89.5 \%)$ & $27(75.0 \%)$ & ns \\
\hline 教育歴 & & & ns \\
\hline · 中学校 & $7\left(36.8^{\circ}\right)$ & $8(22.2 \%)$ & \\
\hline ·高等学校 & $9(47.4 \%)$ & $23(63.9 \%)$ & \\
\hline - 専門学校 - 短大 . 大学 & $3(15.8 \%)$ & $5(13.9 \%)$ & \\
\hline \multicolumn{4}{|l|}{ 経済的背景 } \\
\hline (1)現在仕事がある & $1(5.3 \%)$ & $0(0.0 \%)$ & $\mathrm{ns}$ \\
\hline (2)障害年金老受給 & $14(73.7 \%)$ & $14\left(41.2^{\alpha}\right)$ & * \\
\hline (3)生活保護老受給 & $1(5.3 \%)$ & $6(17.6 \%)$ & ns \\
\hline (4)家族の収入で生活 & $13(68.4 \%)$ & $18\left(52.9_{\%}^{\alpha}\right)$ & ns \\
\hline \multicolumn{4}{|l|}{ 日中の活動 } \\
\hline ・ディケアにに通っている & $11(57.9 \%)$ & $11(32.4 \%)$ & $\mathrm{ns}$ \\
\hline ·作業所等に通っている & $3(15.8 \%)$ & $4(11.8 \%)$ & ns \\
\hline 罹病期間 (年) & $14.1 \pm 8.1$ & $15.7 \pm 10.6$ & ns \\
\hline 前回の人院日数 & $415.7 \pm 776.4$ & $474.6 \pm 893.0$ & ns \\
\hline 退院から調査日までの日数” & $439.5 \pm 405.1$ & $477.5 \pm 710.3$ & ns \\
\hline
\end{tabular}

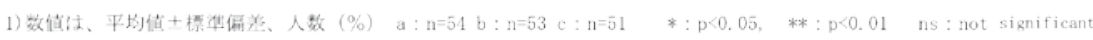

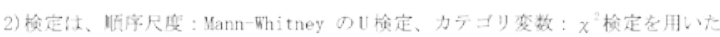

表 4. 初回調査後の入院群と非入院群の精神症状、地域生活における自己効力感、 服薬状況の比較一訪問群を対象としてー

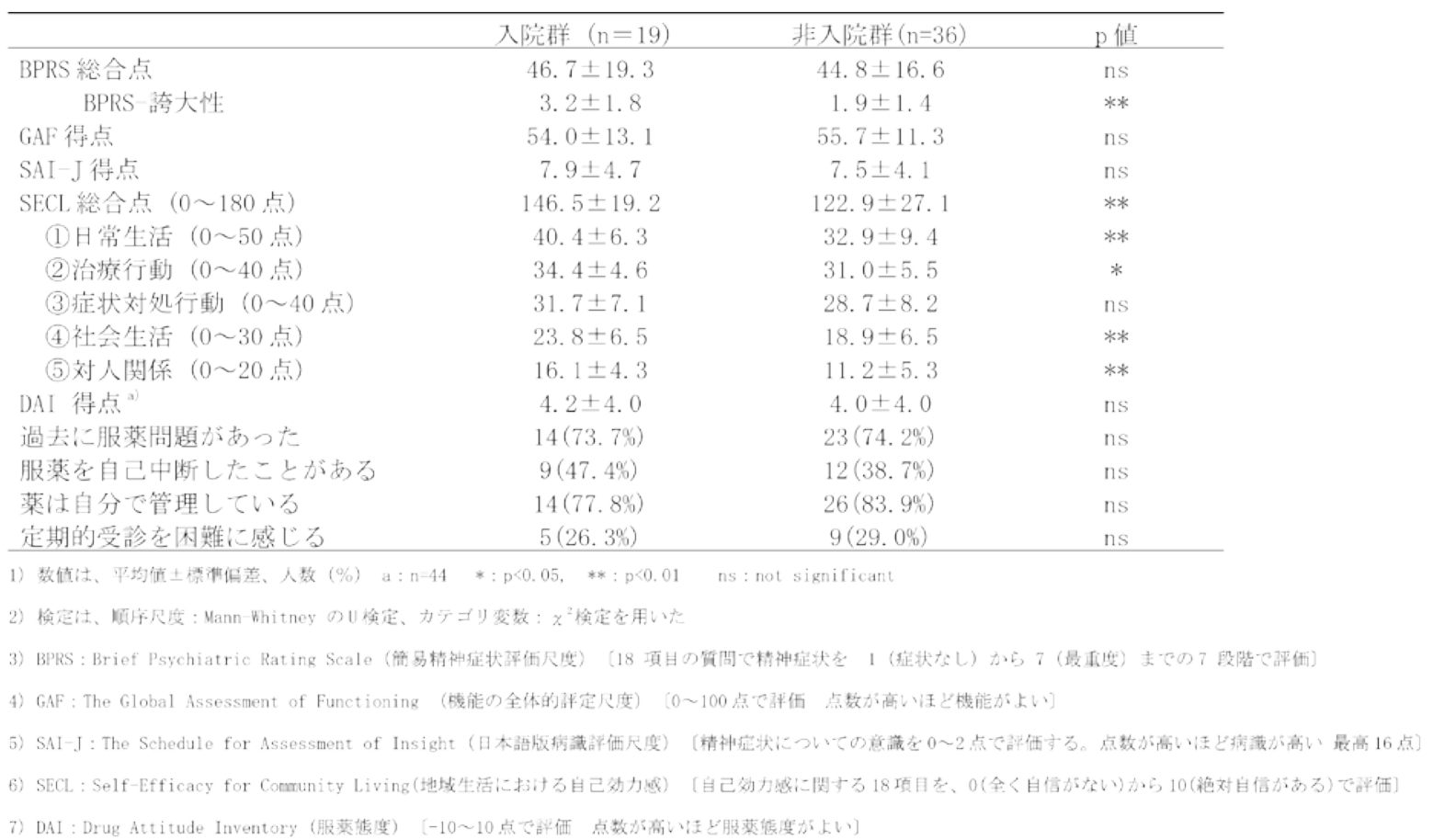

安定で病識が低く日常生活機能の低下があることが明 らかになった。

高齢，統合失調症，退院後の支援が不十分な者の入 院が長期化しやすく ${ }^{3319)}$, 家族の介護㾉労緩和のため の入院も多い ${ }^{20)}$ という報告もある。本研究では, 全 体の $86 \%$ が家族と同居しており家族の支援により日 常生活が維持できていると考えられた。しかし，訪問
群は非訪問群に比べ，同居の割合が低く $(\mathrm{p}<0.05)$, 年 齢が高いことから $(\mathrm{p}<0.01)$, 親の不在や高齢化等退院 後の生活を家族が支えられない者の入院が長期化して いたと考えられる。精神科訪問看護の利用は, 症状が 重度で家族の支援が困難な統合失調症患者でも在宅生 活を可能にすると思われた。 


\section{2. 訪問看護利用者の再入院の有無と関連要因}

初回調查後平均 9 力月間に入院した者 (入院群) は 19 名であった。再入院の背景に, 精神症状の悪化や 病識の欠如, 服薬の中断等があると考えられるが ${ }^{31}$, 本研究では, 初回調査時の入院群と非入院群を比較 した際，精神症状，服薬態度，病識に有意差は認めら れなかった。しかし，入院群では，SECLの得点(自 己効力感)や BPRS(精神症状)の下位項目の「誇大性」: 過大な自己評価により自己の能力を確信する，が非入 院群に比して有意に高く $(\mathrm{p}<0.01)$, 自身の能力を過大 評価していたと推測できる。

入院患者の SECL (地域生活における自己効力感) の得点が外来患者より高く, 陽性症状が重篤で誇大性 や判断力, 病識の欠如などが認められたという報告も ある ${ }^{18)}$.

本研究でも入院群の SECL の総得点及び BPRS の 下位項目の「誇大性」の平均得点が非入院群と比較し 有意に高く，自身の能力に対する過信があったと考え られた。

また, SECL(自己効力感) と BPRS( 精神症状) の相 関をみると, 非入院群で, 自己評価の SECL(得点が 高いほど自信がある) と他者評価の BPRS(得点が高 いほど精神症状が重篤) に負の相関が認められ，症状 が重度な者は, 自己効力感が低く一致していると考え られたが，入院群では相関が認められず，他者評価と 自己評価が一致していなかった，統合失調症は，障害 認識やセルフモニターの障害が治療に影響を与えると 言われ ${ }^{211}$ ，幻聴や妄想に支配されると，物事を判断す る物差しを見失い自力で解決できない時がある ${ }^{22}$. 入 院群の自己効力感が非入院群より高かったことより, 再入院者は, 社会経験の乏しさや症状の悪化による現 実認知能力の低下等で自己の能力を過大に評価し, 生 活リズムを乱したのではないかと推測される。定期的 に自宅を訪問し，病状を把握することができる精神科 訪問看護は, 地域で暮らす精神障害者が精神症状や日 常生活に対する自己管理能力を高め, 症状を悪化させ ないようにするために重要な役割を担っている。

\section{3. 精神科訪問看護の役割}

自己効力感が高い者が再入院していたことょり，地 域で暮らす統合失調症患者が，日常生活に対する能力 を過信しないように働きかけ，治療が継続できるよう に支援することが訪問看護の役割であると考える。ま た，在宅で療養する患者が自立した生活を送り，医療 にアクセスしやすい環境を整えるためには経済的な側 面も考慮しなければならない。精神科の通院患者に生
活の不安を尋ねた調査 ${ }^{20)}$ では「病気の再発や悪化」 に次いで，「経済的なこと」「仕事を見つけられるか」 という内容が上位であった。

精神障害者が地域生活を継続するためには，服薬管 理や日常生活の支援に加え経済的な問題に対する支援 も必要である。統合失調症患者は, 人付き合いが苦手 な者も多く, 緊張や不安によるストレス, 集中力や意 欲の低下等によって仕事を継続できない，体調の悪化 や受診のために仕事を休まないといけないなど就労が 困難な状況がある。本研究においても, 教育歴が短い 者が多く，「収入になる仕事がある」と回答した者は， 訪問群 $1.8 \%$, 非訪問群 $19.4 \%$ であり, 就労の内容は 自営業の手伝いやアルバイト, 作業所等であり, 自立 した生活を送ることが困難な状況があった。精神科訪 問看護は, 精神保健福祉士や作業療法士との訪問も可 能であり, 就労支援や福祉制度などの活用, 生活機能 の回復のためのリハビリテーションなど幅広いニーズ に応じることができる，多様な背景のスタッフが連携 し専門性を発揮することが, 精神障害者の地域生活支 援体制を強化するために重要であると考える。

精神科訪問看護は, 患者の自宅を活動の場とするた め生活の場で生じる様々な問題を患者と共有し周囲に 伝えることができる．利用者が抱える個別の問題が地 域の問題となるような地域連携のあり方や個々のニー ズにそった効果的な活動を展開する方法について今後 明らかにする必要がある。

本研究の限界として, 対象者数も少なく, 茨城県の 一地域の一施設での調査であるため対象者に偏りがあ る可能性があり, 結果を全ての地域在住の統合失調症 患者に普遍化することは困難である。しかし，全国精 神科病院の外来患者の特性と近似していることから一 般的な統合失調症の外来患者を反映していると考えら れる. 精神科訪問看護を利用している者の特性や入院 に関連する要因が明らかとなり, 精神科に通院する患 者が訪問看護を利用しながら在宅での生活を継続して いく上での貴重な資料となり有用であると考える。今 後は, 多地域·多施設における調查を行う必要がある.

\section{V. 結論}

精神科外来患者で訪問看護を利用している統合失調 症患者の特性を明らかにした，全体の $86 \%$ が家族と 同居していたが, 訪問看護利用者は年齢が高く, 単独 世帯の者, 精神症状が重度で再発の恐れが高く, 継続 した支援を必要とする者が多かった。精神科訪問看護 の利用は, 高齢化など家族の支援が困難で症状が重度 
な統合失調症患者の在宅生活を可能にすることが示唆 された。また, 訪問看護利用者で自己効力感の高い者 が再入院していたことより, 患者が自己の能力を適切 に判断し，疾病管理ができるような働きかけが訪問看 護に求められていると考える.

\section{謝辞}

本研究の一部は, 平成 21 年度茨城県立医療大学地 域貢献研究の助成を受けて行われた。データ収集にご 協力いただいた皆様及び $\mathrm{M}$ 病院のスタッフの方々に 感謝申し上げます。

\section{文献}

1) 大島嚴. ACT・ケアマネジメント・ホームヘルプサー ビス - 精神障害者地域生活支援の新デザイン -。精神 看護出版, 東京, 2004, p.113-136.

2) 厚生労働省. 今後の精神保健医療福祉のあり方等 に関する検討会について。

http://www.mhlw.go.jp/shingi/2008/09/s0903-5. html(2010-2-28)

3) 白石弘已. 平成 19 年度厚生労働科学研究補助金(こ ころの健康科学研究事業)

「精神科新規入院患者の動態に関するアンケート調査」 報告書, http://www.ncnp.

go.jp/nimh/keikaku/vision/pdf/new_admission_ survey.pdf(2010-3-16)

4) 萱間真美. 精神障害者の看護, 日本看護協会出版会, 東京, 2007, p.7-60.

5) 厚生統計協会. 厚生の指標 臨時増刊国民衛生の 動向 2008 年, 第 55 巻, p.112-116.

6) 畑田けい子, 中根允文. 服薬コンプライアンスと 分裂病の長期転帰. 臨床精神医学. 1999, vol.28, p.609-614.

7) 新井信之, 内山範夫, 佐藤哲郎. 精神障害者の賃 貸アパート契約に至る現状と支援の課題. 順天堂大学 医療看護学部 医療看護研究. 2007, vol.3, p.9-14.

8) 原昌平, 他. アンチスティグマ社会を動かす当事 者とメディアの役割.精神神経学雑誌. 2008, vol.110, p.388-393.

9) Rose,L.E.; Gerson, L.; Carbo, C. Transitional care for seriously mentally ill

persons: a pilot study. Archives of Psychiatric Nursing. 2007, vol. 21, p.297-308.

10) Wiley-Exley,E. Evaluations of community mental health care in low-and idle-income countries: a 10year review of the literature. Social Science \&Medicine. 2006, vol.64, p.1231-1241.

11）萱間真美，松下太郎，船越明子，精神科訪問看護 の効果に関する実証的研究 - 精神科入院日数を指標と した分析. 精神医学. 2005, vol.47, p.647-653.

12) 田川皓一. 神経心理学評価ハンドブック, 西村書 店，東京，2004，p.88-98.

13) 酒井佳永, 金吉晴, 秋山剛, 他. 病識評価尺度 (The Schedule for Assessment of Insight) 日本語版の信頼 性と妥当性の検討. 臨床精神医学. 2000, vol.29, p.177-183.

14) Hogan,T. P.; Award, A. G.; Eastwood, R . A selfreport scale predictive of drug compliance in schizophrenics :reliability and discriminative validity. Psychol. Med. 1983, vol. 13, p. 177-183.

15) 宮田量治, 藤井康男, 稲垣中, 他. 精神分裂病患 者への薬物療法とクオリティ・オブ・ライフ（その 1$)$ 薬に対する構えの調查票 (Drug Attitude Inventory 日 本語版)による検討. 精神神経学雑誌. 1996, vol.98, p.1045-1046.

16）瀬戸屋 (大川) 希, 大島嚴，長直子，他. 統合失 調症の自己記入式調查に対する回答信憑性. 精神医学. 2003, vol.45, p.517-524.

17) 大川希，大島巌，長島直子，他. 精神分裂病者の 地域生活に対する自己効力感尺度

(SECL) の開発〜信頼性. 妥当性の検討. 精神医学. 2001, vol.43, p.727-735.

18）日本精神科病院協会. 精神障害者社会復帰サービ スニーズ等調査事業報告書, http://www.mhlw.go.jp/ shingi/2003/11/s1111-2a.html\#gaiyo (2010 - 2-4)

19) 小山明日香, 石田重信, 丸岡隆之, 他. 精神科急 性期治療病棟退棟患者の特徵と患者の再入院を予測す 万要因. 臨床精神医学. 2004, vol.33, p.1501-1507.

20) 熊谷亮, 榛沢亮, 内海雄思, 他. 順天堂東京江東 高齢者医療センターにおける精神科病棟入院患者の現 状一開院当初と比較して. 順天堂医学. 2008, vol.54, p.468-473.

21) 池淵恵美. 統合失調症のリハビリテーションと認 知機能障害. 臨床精神医学. 2005, vol.34, p.764-774. 22) 蟻塚亮二. 統合失調症とのつきあい方一闘わない ことのすすめ, 大月書店, 東京, 2009, p.144-200. 


\section{Abstract}

Role of psychiatric visiting nurse services for patients with schizophrenia living in the community: Characteristics of recipients of home visits by psychiatric nurses and factors related to their re-hospitalization.

\section{Mikiko Sadamura $^{1)}$ Junko Okuno ${ }^{1)}$ Yuriko Yamakawa ${ }^{2)}$ Hisako Yanagi ${ }^{1)}$}

${ }^{1)}$ Department of Medical Science and Welfare, Graduate School of Comprehensive Human Sciences, University of Tsukuba, 305-8577, Japan

${ }^{2}$ Ibaraki Prefectural University of Health Sciences

OBJECTIVE : The aims of this study were to clarify the characteristics of outpatients with schizophrenia receiving psychiatric nursing at home and to evaluate factors related to re-hospitalization. METHODS : The subjects were 55 outpatients with schizophrenia who were receiving psychiatric home visits and 31 non-users. An interview was conducted based on a questionnaire on age, gender, family members, psychiatric symptoms, attitude to drug use, and self-assessment of efficacy etc.; and we examined factors related to re-hospitalization.

RESULTS : Most subjects (86\%) lived with their families. The percentage that lived alone was higher among those receiving nursing visits than non-recipients. Of the average age of the nursing recipients was higher than that of the non-recipients, the mean period of hospitalization was longer and the period after discharge was shorter than for the latter. The self-assessed score for efficacy among the nursing recipients who were re-hospitalized was higher than among those who were not re-hospitalized.

CONCLUSIONS : It is suggested that schizophrenia patients with serious symptoms or without family support can live in the community by using home visits by psychiatric nurses. The visiting nurses are requested to advise the patients so that they are able to assess their own capabilities and to control their own condition.

Key Words : schizophrenia, community health welfare, psychiatric home visit nursing, self-efficacy 